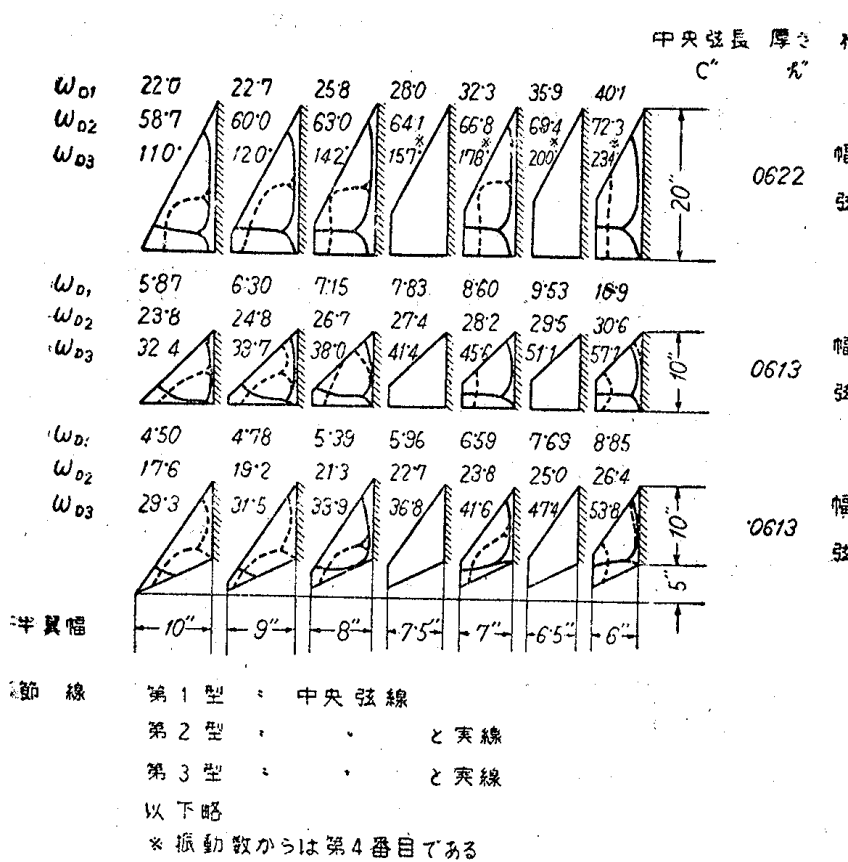

第 28 注

[山内邦比古]

"621.039.4.004.6(71)

[265]原子炉の黑大事故例飞対策 [G.W. Hatfield, Mech. Engg., 1955-2, Vol. 77, No. 2, p. 124 126, 図 4] 1952 年 12 月 12 日にカナダの NRX 原子炉 (重水隇速, 天然水冾却) の停止用調節棒汇機践 的故啅が生じ，発生熱量が急增した。その結果冷却”水

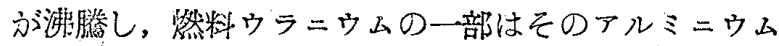
容器と其にとけてしまった。この原子炉では需水法カ ランドリヤ中にあり，その闻端面に多数のアルミニウ 公管をエキスパンドで取付け，管内に然料管が同心的 にはいっているが，カランドリヤにとりつけた管も一 部破裂した。地下窒と計器等が浸水したが、冷却水を とめるウラニウムが発火する打れがあるのでとめられ ない. 地下室の水は屋外タンクにくみ出したがこれは 5 日間で一杯になったので，1マイル以上はなれた所

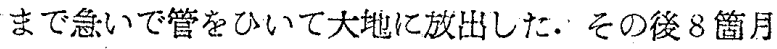
加かって原子炣を分解したが，一切を邀隔操縦でする 必要のために大変な苦労をした．取外した部分品は修 理の上もとの場所に使用したが，取外しの際にやむを 得ずひどく被壊したものだけは新品で扣きかえた。現 在では停止用調節棒には二軍の独立の澡綎装置設設け たり，ての他種ぬの改良を施して使用している。然 水や重水を使う原子炬では，泌射能で強く污染された 大量の水をすててもよい場浙を確保して报く必要があ る.重大等故を起すとどうしても人間が放射能のある
を后場所に大らねばならないから，

$\mathcal{F}_{\mathrm{g}}$ 建物や莜気装置をあら方しめと

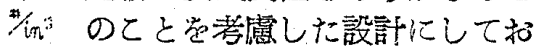

28: 〈必要お゙ある.〔石谷 筒幹〕

\section{$621-51: 612.8$}

[236]祴㧴設䚺のための人間

工学 [W.E. Woodson, Human 䁏方向 $29.2 \times 10^{6} \quad 281$ engineering guide for equip弦方向 $27.8 \times 10^{\circ}$ ment designers, 1954 ,pp. 246, B 5, Univ. of California Press,

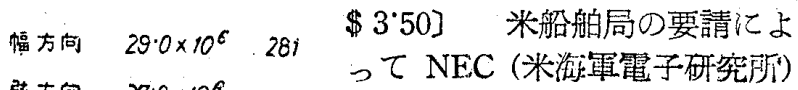
弦方向 $278 \times 10^{6}$ 方, 医学研究所, 航空医研，乙 の他研究所, 大学, 工場などの 協才を得てまとめたもので，計

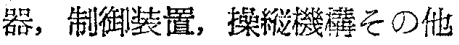
人間方泪係する機械部分の設語。 に役立たせようとするものであ る.内容は 1. 目盛, つまみ,

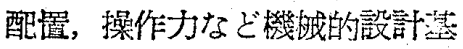
準, 2. 視覚, 3. 聴賞, 4. 人間測定, 5. その他.に 分かれている。

1.では指示登は主䅐線の $\pm 30^{\circ}$ 以内の乙と，操作 ヘタルクは $23 \mathrm{~kg} \cdot \mathrm{cm}$ まで, ブレーキべタルは $226 \mathrm{~kg}$ まで，P型指示ブラウン管などでは直立位で見るもの は水平と $30^{\circ}$, 高座位で $45^{\circ}$, 座 (いす) 位で $60^{\circ}$ パ ネルを傾けるのがよい，講堂などでは最前席の偪は幕 からの而角 $60^{\circ}$ 以内に, 距離は筑幅の 2 倍上上, 最後 席は 6 倍以内にとる. 階段は 30〜 $45^{\circ}$ の傾科に, 加 速度は $+5 \mathrm{~g} ，-4 \mathrm{~g}$ を越すと目が見えなくなり，短 時間では $30 \sim 40 \mathrm{~g}$ に耐える。

2. では暗順応，色感，速度 200 度/s で分解芯が 1/10 になるとと, $590 \mathrm{~m} \mu$ の黄が分解最能大のとと。

3. では吾楽仗よる作栄能率の向上, 事故低下.

4. では手足の作動筑囲，手の引張力が酸時 $110 \mathrm{~kg}$, 連続 $30 \mathrm{~kg}$, 持上げは $200 \mathrm{~kg}$.

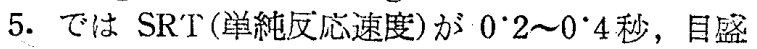
追随などの操作能才，亿おい，味，慨，のどのかわき，

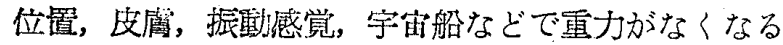
と，手足の運動が大げさになり，かつ藸しい"船配い” が甬愁される他は感覚に大きな影響のないこと。

などが目についた点，米人を刘照にしているので大 きさや力(たとえばブレーキ力)など我ねと一致しない

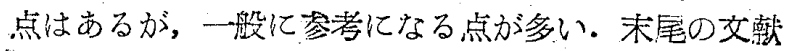
集がはんど米国内発行のものに限られているのはち よっと寂しい. 插桧は香逸.

[青木 和崖] 